JIEB (ISSN : 2442-4560) available online at : ejournal.stiepancasetia.ac.id

\title{
ANALISIS PENGARUH TRANSFER PELATIHAN TERHADAP PRESTASI KERJA PETUGAS PROMOSI KESEHATAN PUSKESMAS KABUPATEN KOTAWARINGIN TIMUR
}

\author{
Zainul Hakim \\ Akademi Keperawatan Pemerintah Kabupatan Kotawaringin Timur \\ Jl. Batu Berlian No.11 Sampit Kalimantan Tengah, \\ e-mail : akbarz25@yahoo.com
}

\begin{abstract}
This Study aims to know the effect of training transfer consisting of individual, motivational, and environment simultaneously and partially on the performance of health promotion officer of East Kotawaringin District Health Center. Descriptive research method Analysis is used with a sample of 38 respondents with sampling techniques use census techniques, analized using linier regression multiple analysis. The results of this study indicate that training transfer consisting of individual, motivasional, and environmental variables simultaneously has an effect on the performance of health promotion officer of Kotawaringin Timur District Health Center, while partially only individual and motivational variables have a significance influence on health promotion officer performance in Kotawaringin Timur District Health Center. The influence of individual variable to health worker health promotion officer performance of East Kotawaringin Regency Health Center stronger than motivational variable.
\end{abstract}

Keywords : Transfer Training, Individual, Motivasional, Environment, Work Achievement

\begin{abstract}
Abstrak : Penelitian ini bertujuan untuk mengetahui pengaruh transfer pelatihan yang terdiri dari individual, motivasional, dan lingkungan secara simultan maupun parsial terhadap prestasi kerja petugas promosi kesehatan puskesmas Kabupaten Kotawaringin Timur. Metode penelitian yang digunakan adalah Deskriptif Analisis dengan sampel sebanyak 38 responden dengan teknik pengambilan sampel adalah teknik jenuh/sensus, teknik analisis menggunakan Analisis Regresi Linear Berganda. Hasil penelitian ini menunjukkan bahwa transfer pelatihan yang terdiri dari variabel individual, motivasional, dan lingkungan secara simultan mempunyai pengaruh terhadap prestasi kerja petugas promosi kesehatan puskesmas Kabupaten Kotawaringin Timur, sementara secara parsial hanya variable individual dan motivasional yang pengaruhnya signifikan terhadap prestasi kerja petugas promosi kesehatan puskesmas Kabupaten Kotawaringin Timur. Pengaruh variabel individual terhadap prestasi kerja petugas promosi kesehatan puskesmas Kabupaten Kotawaringin Timur lebih kuat dibandingkan variabel motivasional.
\end{abstract}

Kata Kunci : Transfer Pelatihan, Individual, Motivasional, Lingkungan, Prestasi Kerja

\section{Latar Belakang}

Persaingan yang semakin tajam, perubahan tehnologi yang cepat, serta perubahan lingkungan yang cenderung radikal yang terjadi hampir pada semua aspek kehidupan manusia sebagai dampak globalisasi, telah menimbulkan pergeseran dan paradigma baru. Perubahan-perubahan tersebut disatu sisi merupakan ancaman bagi kelangsungan hidup, tetapi disisi yang lain justru memunculkan peluang-peluang bagi suatu instansi untuk mengembangkan 
pelayanannya. Kondisi tersebut merupakan kekuatan pendorong bagi suatu organisasi dan para pegawai untuk melakukan transformasi dalam setiap kegiatan yang dilakukan agar dapat mengikuti menyesuaikan dan memanfaatkan setiap peluang dan tantangan serta mengantisipasi setiap ancaman yang ada untuk dapat survive dan menciptakan keunggulan kompetitif yang berkesinambungan (suistainable competitive advantage).

Upaya mentransformasi organisasi diperlukan pembaharuan kembali dalam investasi sumber daya manusia. Modal manusia (human capital), selayaknya dinilai kembali, dimana penekanan pada kompetensi ini (core competence), kapabilitas, dan proses pembelajaran merupakan subyek dalam proses pengembangan sumberdaya manusia. Peningkatan pengetahuan, skill, perubahan sikap, perilaku, koreksi terhadap kekurangankekurangan kinerja dibutuhkan untuk meningkatkan prestasi kerja dan produktivitas.

Bassi, Benson, dan Cherry (1996) dalam Syahruli (2004) menjelaskan salah satu kecenderungan yang akan terjadi ditempat kerja yang perlu diantisipasi dalam mempersiapkan sumberdaya manusia dan tenaga kerja menjelang dan dalam abad 21 adalah kebutuhan keterampilan akan berlanjut selaras dengan meningkatnya perubahan.

Program pelatihan mutlak diperlukan, meskipun merupakan investasi yang mahal (Cheng dan Ho, 1999). Program pelatihan merupakan suatu kekuatan yang diharapkan dapat menciptakan nuansa baru dalam upaya mempercepat pembinaan sumberdaya manusia dengan kompetensinya, kemampuan dan tingkat profesionalisme yang sesuai dengan kebutuhan dunia kerja dan pembangunan menjelang pasar bebas dan dalam abad ke 21 (Baso,1999).

Tracy, et al (2001) menyatakan bahwa mengembangkan dan melaksanakan program pelatihan yang efektif bukanlah pekerjaan yang mudah. Harus dilakukan pertimbangan yang matang sehubungan dengan banyaknya variabel dan isu-isu yang terkait. Beberapa isu penting yang terkait dalam proses pelatihan, diantaranya adalah analisis kebutuhan pelatihan (training needs analysis) (Danerson, 1994: Chiung et al, 1999 : Mc Clelland, 1994), dan transfer pelatihan (transfer of training), (Cheng dan Ho, 2001).

Dalam penelitian ini akan diteliti khususnya tentang transfer pelatihan. Adapun yang dimaksud dengan transfer pelatihan adalah sebagai penerapan pengetahuan, skill, dan perilaku yang dipelajari dalam pelatihan pada situasi kerja dan selanjutnya memeliharanya selama periode waktu tertentu (Baldwin dan Ford, 1997 : Xiao, 1996 dalam Syahruli, 2004).

Perubahan perilaku dan peningkatan pengetahuan serta skill tidak akan berarti banyak apabila penerapan dalam situasi kerja tidak memberikan dampak peningkatan prestasi (Simamora, 2001). Meskipun demikian, transfer pelatihan bukanlah hal yang sederhana. Terdapat berbagai macam faktor yang mempengaruhinya. Menurut Baldwin dan Fort,1988 dalam Syahruli, 2004, ada tiga faktor yang mempengaruhi proses transfer pelatihan, yaitu karakteristik peserta pelatihan, desain pelatihan, dan lingkungan kerja. Dari beberapa penelitian ditemukan kenyataan bahwa, hanya $10 \%$ dari pengetahuan total untuk pelatihan yang memberikan kontribusi positif pada transfer pelatihan di Amerika Serikat (Georgenson, 1982). Menurut Newstrom (1986), rata-rata dari suatu pelatihan, setelah pelatihan selesai dilaksanakan, hanya $41 \%$ dari materi pelatihan yang diterapkan di tempat kerja

Menurut Steers (1984) mengemukakan umumnya orang percaya, bahwa prestasi kerja individu merupakan fungsi gabungan dari tiga faktor, yaitu : Kemampuan, perangai, dan minat seorang pekerja, Kejelasan dan penerimaan atas penjelasan peranan seorang pekerja dan Tingkat motivasi kerja.

Byar dan Rue yang disadur dari buku Edi Sutrisno (2009, hal. 166) mengemukakan adanya dua faktor yang mempengaruhi prestasi kerja, yaitu faktor individu dan faktor lingkungan.

Puskesmas adalah Organisasi fungsional yang menyelenggarakan upaya kesehatan yang bersifat menyeluruh, terpadu, merata, dapat diterima dan terjangkau oleh masyarakat, dengan peran serta aktif 
masyarakat dan menggunakan hasil pengembangan ilmu pengetahuan dan teknologi tepat guna, dengan biaya yang dapat dipikul oleh pemerintah dan masyarakat. Upaya kesehatan tersebut diselenggarakan dengan menitikberatkan kepada pelayanan untuk masyarakat luas guna mencapai derajad kesehatan yang optimal, tanpa mengabaikan mutu pelayanan kepada perorangan.

Puskesmas di Kabupaten Kotawaringin Timur merupakan tumpuan Dinas Kesehatan dan masyarakat untuk mengelola dan meningkatkan derajat kesehatan di daerah karena puskesmas adalah ujung tombak dan bahkan sebagai pioneer dalam pelayanan kesehatan di lingkungan masyarakat daerah Kabupaten Kotawaringin Timur.

Tenaga kesehatan masyarakat (Kesmas) khususnya Petugas Promosi Kesehatan merupakan bagian dari sumber daya manusia yang sangat penting perannya dalam pembangunan kesehatan dalam Sistem Kesehatan Nasional (SKN). Pembangunan kesehatan dengan paradigma sehat merupakan upaya meningkatkan kemandirian masyarakat dalam menjaga kesehatan melalui kesadaran yang lebih tinggi pada pentingnya pelayanan kesehatan yang bersifat promotif dan preventif.

Sebagaimana tercantum dalam Keputusan Menteri Kesehatan Nomor 1114 /MENKES/SK/VII/2005 tentang Pedoman Pelaksanaan Promosi Kesehatan di Daerah, promosi kesehatan adalah upaya untuk meningkatkan kemampuan masyarakat melalui pembelajaran dari, oleh, untuk dan bersama masyarakat, agar mereka dapat menolong diri sendiri, serta mengembangkan kegiatan yang bersumber daya masyarakat, sesuai sosial budaya setempat dan didukung kebijakan publik yang berwawasan kesehatan.

Pelayanan promotif untuk meningkatkan kemandirian dan peran serta masyarakat dalam pembangunan kesehatan diperlukan program penyuluhan dan pendidikan masyarakat yang berjenjang dan berkesinambungan sehingga dicapai tingkatan kemandirian masyarakat dalam pembangunan kesehatan. Dalam program promotif membutuhkan tenaga-tenaga kesehatan masyarakat yang handal terutama yang mempunyai spesialisasi dalam penyuluhan dan pendidikan (Petugas Promosi Kesehatan). Pelayanan promotif dan preventif untuk menjamin terselenggaranya pelayanan kesehatan ini memerlukan para tenaga kesehatan masyarakat yang memahami tehnik dan metode promosi kesehatan.

Pelatihan merupakan wahana untuk membangun sumber daya manusia menuju era globalisasi yang penuh dengan tantangan, untuk memperoleh dan meningkatkan keterampilan di luar system pendidikan yang berlaku dalam waktu yang relatif singkat dengan metode yang lebih mengutamakan praktik daripada teori, sehingga dapat meningkatkan kinerja saat ini dan kinerja di masa mendatang.

Untuk meningkatkan sumber daya manusia kesehatan yang mempunyai pengetahuan dan skill yang luas, maka Dinas Kesehatan Kabupaten Kotawaringin Timur melalui Bidang Promosi Kesehatan \& Pengembangan telah melaksanakan pelatihan bagi petugas promosi kesehatan yang pembiayaannya dibebankan pada APBD Kabupaten Kotawaringin Timur.

Berdasarkan pengamatan penulis dari kenyataan bahwa pekerjaan yang diberikan atau dikerjakan tidak tepat waktu atau berlarut-larut sehingga tidak sesuai dengan target yang diinginkan, masih lemahnya disiplin kerja, dan lingkungan kerja kurang bagus atau kurang mendukung aktivitas kerja.

Dalam beberapa penelitian dikemukakan bahwa kesuksesan tahap-tahap dalam proses transfer pelatihan dipengaruhi oleh faktor-faktor individual, motivasional dan lingkungan. Ketiga faktor inilah yang akan penulis analisis dalam penelitian ini.

Berdasarkan pada latar belakang diatas, dapat dilihat bahwa pengaruh faktor-faktor transfer pelatihan terhadap prestasi kerja sangat penting dipahami oleh Dinas Kesehatan Kabupaten Kotawaringin Timur dan Puskesmas, agar dapat mencapai tujuan organisasi yang lebih baik dan tepat sehingga sesuai dengan harapan.

Berdasarkan uraian pada latar belakang diatas, maka pokok permasalahan yang 
diajukan dalam penelitian ini adalah sebagai berikut :

1. Apakah transfer pelatihan yang terdiri dari individual, motivasional, dan lingkungan secara parsial berpengaruh terhadap prestasi kerja petugas promosi kesehatan puskesmas Kabupaten Kotawaringin Timur?

2. Apakah transfer pelatihan yang terdiri dari individual, motivasional, dan lingkungan secara simultan berpengaruh terhadap prestasi kerja petugas promosi kesehatan puskesmas Kabupaten Kotawaringin Timur?

3. Dari transfer pelatihan yang terdiri dari Individual, motivasional, lingkungan, manakah yang berpengaruh dominan terhadap prestasi kerja petugas promosi kesehatan puskesmas Kabupaten Kotawaringin Timur?

\section{Studi Literatur}

Pengertian Pelatihan, Pelatihan (training) merupakan proses pembelajaran yang melibatkan perolehan keahlian, konsep, peraturan, atau sikap untuk meningkatkan kinerja karyawan.

Menurut pasal 1 ayat 9 Undang-undang No. 13 Tahun 2003 tentang ketenagakerjaan, mendefenisikan pelatihan adalah keseluruhan kegiatan untuk memberi, memperoleh, meningkatkan, serta mengembangkan kompetensi kerja, produktivitas, disiplin, sikap dan etos kerja pada tingkat keterampilan dan keahlian tertentu sesuai dengan jenjang dan kualifikasi jabatan dan pekerjaan.

Pelatihan terdiri atas serangkaian aktivitas yang dirancang untuk meningkatkan keahlian, pengetahuan, pengalaman, ataupun perubahan sikap sesorang. Program pelatihan berusaha mengajarkan kepada para peserta bagaimana menunaikan aktivitas atau pekerjaan tertentu. Dalam pelatihan diciptakan suatu lingkungan dimana para karyawan dapat memperoleh atau mempelajari sikap, kemampuan, keahlian, pengetahuan, dan perilaku yang spesifik yang berhubungan dengan pekerjaan. Pelatihan biasanya terfokus pada penyediaan keahlian khusus bagi para karyawan atau membantu mereka membenahi kelemahan kinerja mereka. Melalui pelatihan dilakukan segenap upaya untuk meningkatkan kinerja pegawai pada pekerjaan yang diduduki sekaranag..

Dalam Proses Pelatihan dan Pengembangan orang-orang kompeten dapat disediakan melalui dua cara di dalam organisasi. Pertama, organisasi dapat menyeleksi orang-orang terbaik yang tersedia. Kedua, orang-orang yang ada didalam perusahaan dapat dilatih dan dikembangkan untuk mengerahkan potensi penuh mereka. Pada intinya, kedua ancangan itu merupakan bagian dan proses yang sama karena begitu seorang individu diseleksi dia haruslah menjalani beberapa pelatihan, terlepas dari apapun kualifikasinya. Maka dari itu, pelatihan dan pengembangan karyawan harus diadakan.

Manfaat Pelatihan program pelatihan dan pengembangan :

1. Meningkatkan kuantitas dan kualitas produktivitas.

2. Mengurangi waktu belajar yang diperlukan karyawan untuk mencapai standar kinerja yang dapat diterima.

3. Membentuk sikap, loyalitas, dan kerja sama yang lebih menguntungkan.

4. Memenuhi kebutuhan perencanaan sumber daya manusia.

5. Mengurangi frekwensi dan biaya kecelakaan kerja.

6. Membantu karyawan dalam peningkatan dan pengembangan pribadi mereka.

Dalam suatu organisasi, setiap pegawai dituntut untuk menyelesaikan tugas-tugasnya seefektif dan seefisien mungkin. Selain itu penyelesaian tugas-tugas dari seorang pegawai merupakan suatu bukti nyata tentang sejauh mana prestasi yang telah dicapainya.

Menurut (Musanef: 1996 : 162) dalam bukunya Manajemen Kepegawaian di Indonesia mengemukakan bahwa :"Prestasi kerja adalah hasil kerja yang dicapai oleh seorang pegawai dalam melaksanakan tugas yang dibebankan kepadanya".

Selain itu menurut (Hasibuan, 1997 : 105) dalam bukunya Manajemen Sumber Daya Manusia (Dasar dan Kunci Keberhasilan) mengatakan bahwa : "Prestasi kerja adalah suatu hasil kerja yang dicapai seseorang dalam melaksanakan tugas-tugas 
yang dibebankan kepadanya didasarkan atas kecakapan, pengalaman dan kesungguhan kerja serta waktu"

Prestasi tersebut kemudian dapat dinilai melalui penilaian prestasi kerja yang merupakan suatu proses untuk mengukur hasil kerja yang dicapai oleh pekerja dan dibandingkan terhadap standar tingkat prestasi yang diminta guna mengetahui sampai dimana keterampilan telah dicapai dan kemudian dipakai sebagai pertimbangan untuk menemukan kelemahan-kelemahan tersebut, perencanaan karier, serta sebagai dasar untuk menentukan penghargaan terhadap prestasi dan sebagai titik tolak usaha pribadi.

Jadi prestasi kerja sangatlah diperlukan didalam lingkungan organisasi manapun. Karena dengan adanya prestasi kerja yang sesuai dengan yang diharapkan maka efisiensi suatu organisasi dapat terwujud.

Orang yang satu beda dengan yang lainnya selain terletak pada kemampuannya untuk bekerja juga tergantung pada keinginan mereka bekerja atau tergantung pada motivasinya (Thoha, 2010 dalam Noorzain,2012).

Menurut McClelland (2010) dalam Noorzain (2012) seseorang mempunyai motivasi untuk berprestasi jika ia mempunyai keinginan untuk melakukan suatu karya yang berprestasi lebih baik dari prestasi karya orang lain. Ada 3 (tiga) kebutuhan ini menurut McClelland, yakni kebutuhan berprestasi, kebutuhan untuk berafiliasi dan kebutuhan kekuasaan. Ketiga kebutuhan ini terbukti merupakan unsur-unsur yang amat penting dalam menentukan prestasi seseorang dalam bekerja.

Menurut Steers (1984) mengemukakan umumnya orang percaya, bahwa prestasi kerja individu merupakan fungsi gabungan dari tiga faktor, yaitu : Kemampuan, perangai, dan minat seorang pekerja, kejelasan dan penerimaan atas penjelasan peranan seorang pekerja, dan tingkat motivasi kerja.

Menurut Mangkunegara (2005) dalam Lubis (2008), faktor penentu prestasi kerja individu dalam organisasi adalah faktor individu dan faktor lingkungan.
1. Faktor Individu

Secara psikologis, individu yang normal adalah individu yang memiliki integritas yang tinggi antara fungsi psikis dan fisiknya. Konsentrasi yang baik ini merupakan modal utama individu yang mampu mengelola dan mendayagunakan potensi dirinya secara optimal dalam melaksanakan kegiatan atau aktivitas kerja sehari-hari dalam mencapai tujuan organisasi. Faktor-faktor individu yang dimaksud adalah hasil kerja, pengetahuan pekerjaan, Inisiatif, kecekatan mental, sikap, disiplin waktu dan absensi.

\section{Faktor Lingkungan}

Faktor lingkungan kerja organisasi sangat menunjang individu dalam mencapai prestasi kerja Faktor lingkungan organisasi yang dimaksud antara lain uraian jawaban yang jelas, autoritas yang memadai, target kerja yang menantang, pola komunikasi kerja efektif, hubungan kerja harmonis, iklim kerja respek dan dinamis, peluang berkarier dan fasilitas kerja yang relatif memadai. Lingkungan kerja dalam suatu perusahaan sangat penting untuk diperhatikan manajemen. Meskipun lingkungan kerja tidak melaksnakan proses produksi dalam suatu perusahaan, namun lingkungan kerja mempunyai pengaruh langsung terhadap para karyawan yang melaksanakan proses produksi tersebut. Lingkungan kerja yang memusatkan bagi karyawannya dapat meningkatkan kinerja. Sebaliknya lingkungan kerja yang tidak memadai akan dapat menurunkan kinerja. Sebaliknya lingkungan kerja yang tidak memadai akan dapat menurunkan kinerja dan akhirnya menurunkan motivasi kerja karyawan. Suatu kondisi lingkungan kerja dikatakan baik atau sesuai apabila manusia dapat melaksnakan kegiatan secara optimal, sehat, aman dan nyaman. Kesesuaian lingkungan kerja dapat dilihat akibatnya dalam jangka waktu yang lama. Lebih jauh lagi lingkungan-lingkungan kerja yang kurang baik dapat menuntut tenaga kerja dan waktu yang lebih banyak dan tidak mendukung diperolehnya rencangan sistem kerja yang efisien. 
Lingkungan kerja merupakan segala sesuatu yang ada di sekitar karyawan pada saat bekerja, baik yang berbentuk fisik ataupun non fisik, langsung atau tidak langsung, yang dapat mempengaruhi dirinya dan pekerjaanya saat bekerja.

Sedarmayanti (2001) menyatakan bahwa secara garis besar, jenis lingkungan kerja terbagi menjadi 2 yakni : (a) lingkungan kerja fisik, dan (b) lingkungan kerja non fisik.

a. Lingkungan kerja Fisik

Menurut Sedarmayanti (2001), "Lingkungan kerja fisik adalah semua keadaan berbentuk fisik yang terdapat di sekitar tempat kerja yang dapat mempengaruhi karyawan baik secara langsung maupun scara tidak langsung. Lingkungan kerja fisik dapat dibagi dalam dua kategori, yakni lingkungan yang langsung berhubungan dengan karyawan (Seperti: pusat kerja, kursi, meja dan sebagainya) dan lingkungan perantara atau lingkungan umum dapat juga disebut lingkungan kerja yang mempengaruhi kondisi manusia, misalnya :temperatur, kelembaban, sirkulasi udara, pencahayaan, kebisingan, getaran mekanis, bau tidak sedap, warna, dan lain-lain. Untuk dapat memperkecil pengaruh lingkungan fisik terhadap karyawan, maka langkah pertama adalah harus mempelajari manusia, baik mengenai fisik dan tingkah lakunya maupun mengenai fisiknya, kemudian digunakan sebagai dasar memikirkan lingkungan fisik yang sesuai.

\section{b. Lingkungan Kerja Non Fisik}

Menurut Sadarmayanti (2001), Lingkungan kerja non fisik adalah semua keadaan yang terjadi yang berkaitan dengan hubungan kerja, baik hubungan dengan atasan maupun hubungan sesama rekan kerja, ataupun hubungan dengan bawahan". Lingkungan non fisik ini juga merupakan kelompok lingkungan kerja yang tidak bisa diabaikan. Menurut Alex Nitisemito (2000) Perusahaan hendaknya dapat mencerminkan kondisi yang mendukung kerja sama antara tingkat atasan, bawahan maupun yang memiliki status jabatan yang sama di perusahaan. Kondisi yang hendaknya diciptakan adalah suasana kekeluargaan, komunikasi yang baik, dan pengendalian diri.

Yang menjadi indikator-indikator lingkungan kerja menurut Sedarmayanti (2001) adalah penerangan, suhu udara, suara bising, penggunaan warna, ruang gerak yang diperlukan, keamanan kerja, dan hubungan karyawan.

Keputusan Menteri Kesehatan Nomor 1114/MENKES/SK/VII/2005 tentang Pedoman Pelaksanaan Promosi Kesehatan di Daerah, promosi kesehatan adalah upaya untuk meningkatkan kemampuan masyarakat melalui pembelajaran dari, oleh, untuk dan bersama masyarakat, agar mereka dapat menolong diri sendiri, serta mengembangkan kegiatan yang bersumber daya masyarakat, sesuai sosial budaya setempat dan didukung kebijakan publik yang berwawasan kesehatan

Menyadari rumitnya hakikat dari perilaku, maka perlu dilaksanakan strategi promosi kesehatan paripurna yang terdiri dari (1) pemberdayaan, yang didukung oleh (2) bina suasana dan (3) advokasi, serta dilandasi oleh semangat (4) kemitraan.

Memperhatikan strategi promosi kesehatan tersebut di atas, maka dapat dikatakan bahwa terdapat dua kategori pelaksana promosi kesehatan, yaitu (1) setiap petugas kesehatan dan (2) petugas khusus promosi kesehatan (disebut penyuluh kesehatan masyarakat).

Beberapa penelitian terdahulu yang membahas hal serupa meliputi:

1. Iswahyu Hartati (2005)

Melakukan penelitian kesesuaian kompensasi dan motivasi Kerja terhadap Prestasi Kerja Pegawai pada sekretariat Daerah Kabupaten Magelang. Hasil penelitian menyebutkan bahwa kompensasi dan motivasi kerja berpengaruh signifikan terhadap prestasi kerja karyawan baik secara individu maupun simultan 
2. Lihut MR Limbong (2006)

Tesisnya yang berjudul "Pengaruh Pemberian Motivasi, Kebutuhan Pegawai dan Kepuasaan kerja terhadap Kinerja Pegawai pada Kantor Pelayanan Perbendaharaan Negara Cirebon" mengemukakan bahwa pemberian motivasi kebutuhan pegawai dan kepuasaan kerja secara bersama-sama berpengaruh positif terhadap kinerja Pegawai pada Kantor Pelayanan Perbendaharaan Negara Cirebon. Hal ini dibuktikan dari hasil uji $F$ yang menunjukkan significant pada taraf $\alpha$ sebesar $1 \%$ dan koefisien determinasi $\left(\mathrm{R}^{2}\right)$ sebesar 0,912.

2. Vera Parlinda dan M. Wahyuddin (2008) Tesisnya berjudul "Pengaruh Kepemimpinan, Motivasi, Pelatihan, dan Lingkungan Kerja Terhadap Kinerja Karyawan pada Perusahaan Daerah Air Minum Kota Surakarta" mengemukakan bahwa Berdasarkan hasil analissis data di atas, maka dapat disimpulkan sebagai berikut: Hasil analisis menunjukkan bahwa variabel pelatihan dan lingkungan kerja mempunyai pengaruh positif dan signifikan terhadap kinerja karyawan pada Perusahaan Daerah Air Minum Surakarta. Variabel kepemimpinan dan motivasi menurut analisa data di muka ternyata tidak signifikan sehingga tidak berpengaruh pada kinerja karyawan Perusahaan Daerah Air Minum Surakarta. Nilai F-hitung sebesar 29,809. Artinya bahwa secara bersama-sama faktor kepemimpinan, motivasi, pelatihan, dan lingkungan kerja berpengaruh terhadap kinerja karyawan Perusahaan Daerah Air Minum Surakarta. Koefisien Determinasi (R2) diperoleh sebesar 0,620. Hal ini berarti variabel independen (kepemimpinan, motivasi, pelatihan, dan lingkungan kerja) mampu menjelaskan $62 \%$ terhadap variabel dependennya (kinerja karyawan), sedangkan sisanya sebesar 38\% dijelaskan oleh variabel lain.

\section{Suyanto (2012)}

Melakukan penelitian dengan judul Pengaruh Kompensasi, Kepemimpinan dan Motivasi Kerja Terhadap Prestasi Kerja Karyawan Pada PT. Permodalan Nasional Madani (Persero) Kantor Cabang Banjarmasin. Hasil penelitian menunjukkan bahwa kompensasi, kepemimpinan, dan motivasi baik parsial maupun simultan berpengaruh terhadap prestasi kerja karyawan PT. Permodalan Nasional Madani (Persero) Kantor Cabang Banjarmasin. Kompensasi merupakan variabel yang dominan berpengaruh terhadap prestasi kerja karyawan PT. Permodalan Nasional Madani (Persero) Kantor Cabang Banjarmasin.

4. Heriansyah (2012)

Melakukan penelitian dengan judul Analisis Pengaruh Kepemimpinan, Insentif, Kondisi Lingkungan Kerja, Kesempatan Promosi dan Supervisi Terhadap Tingkat Kepuasan Kerja Perawat di Ruang Rawat Inap RSUD Kotabaru. Hasil analisis dalam penelitian : (1) variabel yang berpengaruh dominan terhadap kepuasan kerja perawat adalah kesempatan promosi, (2) kepemimpinan tidak berpengaruh terhadap kepuasan kerja perawat, (3) insentif berpengaruh terhadap kepuasan kerja perawat, (4) kondisi lingkungan kerja tidak berpengaruh terhadap kepuasan kerja perawat, (5) kesempatan promosi berpengaruh terhadap kepuasan kerja perawat, (6) supervisi berpengaruh terhadap kepuasan kerja perawat, dan (7) secara simultan (kepemimpinan, insentif, kondisi lingkungan kerja, kesempatan promosi, dan supervisi) berpengaruh terhadap kepuasan kerja perawat.

\section{Metode Penelitian}

Rancangan penelitian ini menggunakan metode deskriptif analisis seperti yang dijelaskan oleh Nur Indriantono (2002 : 89) bahwa "Metode deskriptif analisis dapat digunakan untuk menguji hipotesis atau menjawab pertanyaan penelitian". Demikian juga seperti yang diungkapkan oleh Consuelo dan Husen Umar (2004 : 81) menyatakan bahwa "Metode deskriptif dapat digunakan untuk riset korelasi". 
Sebagai bahan pertimbangan dalam pemilihan metode deskriptif analisis, Lokasi penelitian di 20 Puskesmas Kabupaten Kotawaringin Timur, Jumlah sampel 38 orang petugas promosi kesehatan Puskesmas Kabupaten Kotawaringin Timur. Variabel yang digunakan 3 variabel bebas $(\mathrm{X})$ : Individual (X1), Motivasional (X2), dan Lingkungan (X3) dan 1 variable terikat atau dependen $(Y)$.

Untuk menjamin keabsahan data maka kualitas data yang dihasilkan dari penggunaan instrumen penelitian dapat dievaluasi melalui uji reliabilitas dan validitas, dimana uji ini masing-masing untuk mengetahui konsistensi (reliabilitas) dan keakurasian (validitas) data yang dikumpulkan melalui penggunaan instrumen penelitian (angket). Untuk uji reliabilitas dengan uji Cronbach's Alpha, dimana suatu variabel atau konstruk dikatakan reliabel jika memberikan nilai Cronbach's Alpha lebih besar (>) dari 0,60. Sedangkan pengujian validitas dengan menggunakan uji korelasional Pearson (Pearson Correlation), dengan masing-masing skor butir/indikator dikorelasikan dengan skor total pada tingkat signifikansi $5 \% \quad(0,05)$ pada suatu variabel/konstruk, dimana jika skor butir/indikator positif dan signifikan (di bawah 0,05) maka indikator tersebut dapat disimpulkan valid sebagai indikator variabel/konstruk tersebut.

Dalam penelitian ini model analisis yang digunakan adalah Analisis Regresi Berganda, dimana analisis ini digunakan karena peneliti ingin mengetahui pengaruh transfer pelatihan yang terdiri dari individual, motivasional, dan lingkungan terhadap prestasi kerja petugas promosi kesehatan puskesmas Kabupaten Kotawaringin Timur.

\section{Hasil Penelitian dan Pembahasan}

Kualitas data yang dihasilkan dari penggunaan instrumen penelitian dapat dievaluasi melalui uji reliabilitas dan validitas, dimana uji ini masing-masing untuk mengetahui konsistensi (reliabilitas) dan keakurasian (validitas) data yang dikumpulkan melalui penggunaan instrumen penelitian (angket).
Uji reliabilitas dengan uji Cronbach's Alpha, dimana suatu variabel atau konstruk dikatakan reliabel jika memberikan nilai Cronbach's Alpha lebih besar (>) dari 0,60 (Nunnaly, 1960 dalam Ghozali, 2009 dan Maholtra, 1992 dalam Solimun, 2011). Hasil uji reliabilitas pada penelitian ini menunjukkan nilai Cronbach's Alpha masing-masing indikator variabel lebih besar dari 0,60 , sehingga dapat disimpulkan untuk uji kualitas data pada reliabilitas sudah memenuhi kualitas konsistensi.

Uji validitas dengan menggunakan uji korelasional Pearson (Pearson Correlation), dengan masing-masing skor butir/indikator dikorelasikan dengan skor total pada tingkat signifikansi $5 \% \quad(0,05)$ pada suatu variabel/konstruk, dimana jika skor butir/indikator positif dan signifikan (di bawah 0,05) maka indikator tersebut dapat disimpulkan valid sebagai indikator variabel/konstruk tersebut. Hasil uji validitas dengan Pearson Correlation pada penelitian ini menunjukkan bahwa pada masing-masing variabel yang digunakan dalam penelitian untuk masing-masing indikator yang dikorelasikan dengan skor total masingmasing variabel menunjukkan korelasi positif dan signifikan (di bawah 0,05). Dengan demikian dapat disimpulkan untuk uji kualitas data pada validitas sudah memenuhi kriteria valid atau akurat

Tahapan selanjutnya adalah uji asumsi klasik untuk memastikan kalau model yang digunakan dalam penelitian ini adalah model yang berkualitas, terdiri dari:

1. Uji Multikolinieritas

Dalam penelitian ini hasil besaran korelasi antar variabel independen yang masih di bawah 0,90 , serta dari perhitungan nilai Tolerance ditunjukkan tidak ada nilai variabel independen yang memiliki nilai Tolerance kurang dari 0,10 yang berarti tidak ada ada korelasi antar variabel independen yang nilainya lebih dari $95 \%$. Hasil perhitungan nilai Variance Inflation Factor (VIF) juga menunjukkan hal yang sama, tidak ada satu variabel independen yang memiliki nilai VIF lebih dari 10. Jadi dapat disimpulkan bahwa tidak ada multikolinieritas antar variabel 
independen dalam model regresi yang digunakan dalam penelitian ini.

\section{Uji Heteroskedastisitas}

Hasil uji grafik plot untuk uji heteroskedastisitas yang ditampilkan memperlihatkan bahwa titik-titik menyebar secara acak serta tersebar baik di atas maupun di bawah angka 0 pada sumbu Y. Hal ini dapat disimpulkan bahwa tidak terjadi heteroskedastisitas pada model regresi yang digunakan, sehingga model regresi layak dipakai.

\section{Uji Normalitas}

Tampilan grafik histogram dan normal plot memperlihatkan bahwa data menyebar di sekitar garis diagonal dan mengikuti arah garis diagonal atau grafik histogram juga menunjukkan pola distribusi normal, sehingga secara visual dapat disimpulkan bahwa model regresi yang digunakan dalam penelitian ini memenuhi asumsi normalitas. Selain uji grafik dilakukan juga uji statistik untuk mengkonfirmasi visual uji grafik. Uji statistik yang digunakan adalah uji statistik non-parametrik KolmogorovSmirnov (K-S) pada tingkat kepercayaan $5 \%(0,05)$, dengan dasar pengambilan keputusan, jika tingkat signifikansi hasil uji menunjukkan lebih besar dari 0,05 maka dapat disimpulkan data residual berdistribusi normal. Sebaliknya jika tingkat signifikansi hasil uji menunjukkan lebih kecil dari 0,05 maka dapat disimpulkan data residual berdistribusi tidak normal. Hasil perhitungan menunjukkan besarnya nilai K-S adalah 1,035 dan tidak signifikan $(0,234)$, hal ini berarti data residual terdistribusi normal dan hasil ini konsisten dengan uji grafik.

Tahapan selanjutnya adalah analisis regresi berganda. Dari tampilan output SPSS (Model Summary besar Adjusted $R$ Square $\left(\mathrm{R}^{2}\right)$ adalah 0,912, hal ini berarti $91,2 \%$ variasi Prestasi Kerja (Y) dapat dijelaskan oleh variasi dari ke tiga variabel independen, yaitu individual (X1), motivasional (X2), dan lingkungan (X3). Sedangkan sisanya $8,8 \%$ dijelaskan oleh faktor-faktor lain di luar model penelitian dan error.

\section{Tabel 1. Hasil Uji Model Regresi}

\begin{tabular}{|c|c|c|c|c|}
\hline \multicolumn{5}{|c|}{ Model Summary } \\
\hline $\begin{array}{l}\text { Mo } \\
\text { del }\end{array}$ & $\mathrm{R}$ & $\begin{array}{c}\mathrm{R} \\
\text { Square }\end{array}$ & $\begin{array}{l}\text { Adjusted } \\
\text { R Square }\end{array}$ & $\begin{array}{l}\text { Std. Error of } \\
\text { the Estimate }\end{array}$ \\
\hline 1 & $.959^{\mathrm{a}}$ & .919 & .912 & .623 \\
\hline \multicolumn{5}{|c|}{ a. Predictors: (Constant), X3, X1, X2 } \\
\hline b. De & ndent & ariable: & & \\
\hline
\end{tabular}

Pengujian hipotesis pertama yaitu "Terdapat pengaruh transfer pelatihan yang terdiri dari individual, motivasional,dan lingkungan secara parsial terhadap prestasi kerja petugas promosi kesehatan" dapat dilihat dengan model regresi. Pengujian pengaruh variabel individual (X1) terhadap prestasi kerja petugas promosi kesehatan Puskesmas Kabupaten Kotawaringin Timur diperoleh nilai koefisien positif sebesar 1,166 dengan nilai $t$ statistik sebesar 9,150 dengan tingkat signifikansi 0,000 . Nilai signifikansi t tersebut menunjukkan lebih kecil dari tingkat kepercayaan 0,05 , sehingga dapat disimpulkan bahwa pada tingkat kepercayaan 5\% pengaruh individual terhadap prestasi kerja petugas promosi kesehatan Puskesmas Kabupaten Kotawaringin Timur adalah positif dan signifikan.

Selanjutnya pengujian pengaruh variabel motivasional (X2) terhadap prestasi kerja petugas promosi kesehatan Puskesmas Kabupaten Kotawaringin Timur diperoleh nilai koefisien positif sebesar 0,657 dengan nilai t statistik sebesar 2,736 dengan tingkat signifikansi 0,010. Nilai signifikansi $t$ tersebut menunjukkan lebih kecil dari tingkat kepercayaan 0,05 , sehingga dapat disimpulkan bahwa pada tingkat kepercayaan 5\% pengaruh motivasional terhadap prestasi kerja petugas promosi kesehatan Puskesmas Kabupaten Kotawaringin Timur adalah positif dan signifikan.

Pengujian pengaruh variabel ketiga adalah pengaruh lingkungan (X3) terhadap prestasi kerja petugas promosi kesehatan Puskesmas Kabupaten Kotawaringin Timur diperoleh nilai koefisien positif sebesar 0,348 dengan nilai t statistik sebesar 1,745 dengan tingkat signifikansi 0,090. Nilai signifikansi t tersebut menunjukkan lebih besar dari tingkat 
kepercayaan 0,05 , sehingga dapat disimpulkan bahwa pada tingkat kepercayaan 5\% pengaruh lingkungan terhadap prestasi kerja petugas promosi kesehatan Puskesmas Kabupaten Kotawaringin Timur adalah positif tetapi tidak signifikan.

Pengujian hipotesis kedua yaitu "Terdapat pengaruh transfer pelatihan yang terdiri dari individual, motivasional, dan lingkungan secara simultan terhadap prestasi kerja pegawai" dapat dilihat dari model regresi. Pengaruh variabel-variabel independen (individual, motivasional, dan lingkungan) terhadap variabel dependen (prestasi kerja) secara simultan (bersamasama) menunjukkan nilai $\mathrm{F}$ sebesar 128,389 dengan tingkat signifikansi lebih kecil dari 0,05 (Sig. 0,000). Karena probabilitas lebih kecil dari 0,05, maka dapat diinterpretasikan bahwa individual, motivasional, dan lingkungan secara bersama-sama memiliki pengaruh signifikan terhadap prestasi kerja petugas promosi kesehatan Puskesmas Kabupaten Kotawaringin Timur.

Pengujian hipotesis ketiga dijelaskan dengan cara membandingkan variabelvariabel independen (individu, motivasional, lingkungan). Pengaruh variabel individual (X1) terhadap prestasi kerja petugas promosi kesehatan puskesmas Kabupaten Kotawaringin Timur diperoleh nilai koefisien positif sebesar 1,166 dengan nilai t statistik sebesar 9,150 dengan tingkat signifikansi 0,000. Nilai signifikansi $\mathrm{t}$ tersebut menunjukkan nilai paling kecil dari tingkat kepercayaan 0,05 dibandingkan dengan variabel yang lain (motivasional, lingkungan) sehingga dapat disimpulkan bahwa pada tingkat kepercayaan 5\% pengaruh individual terhadap prestasi kerja petugas promosi kesehatan Puskesmas Kabupaten Kotawaringin Timur adalah variabel yang paling dominan penelitian ini.

Faktor Individual positif dan signifikan dan mempunyai pengaruh yang signifikan terhadap prestasi kerja, dan ini merupakan faktor yang dominan mempengaruhi prestasi kerja petugas promosi kesehatan dalam penelitian ini. Hasil penelitian menunjukkan bahwa petugas promosi kesehatan punya keyakinan dengan mengikuti pelatihan dapat memperbaiki penguasaan pengetahuan, keterampilan dan teknis kerjanya. Hal ini merupakan faktor pendorong sebelum mengikuti pelatihan yang ada dalam diri petugas promosi kesehatan, Tennebeum et al (1991) menyatakan bahwa peserta pelatihan yang mempunyai tingkat keyakinan yang tinggi pada saat pelatihan akan lebih termotivasi untuk mentransfer pengetahuan dan skill yang baru yang diperolehnya selama pelatihan.

Hasil penelitian juga menunjukkan bahwa pegawai mempunyai keyakinan kuat bahwa mereka dapat mengendalikan kehidupannya lebih baik dalam pekerjaannya (seperti peluang promosi, peningkatan gaji, dan perluasan pekerjaan) dengan mengikuti pelatihan, pegawai yang mempunyai keyakinan semacam ini akan lebih memungkinkan untuk menerapkan isi / muatan yang ada dalam pelatihan ke pekerjaannya.

Menurut Kopelman (1988) faktorfaktor yang mempengaruhi kinerja adalah individual characteristics (karakteristik individual), organizational characteristics (karakteristik organisasi), dan work characteristics (karakteristik kerja). Lebih lanjut oleh Kopelman dijelaskan bahwa kinerja selain dipengaruhi oleh faktor lingkungan juga sangat tergantung dari karakteristik individu seperti kemampuan, pengetahuan, keterampilan, motivasi, norma dan nilai.

1. Faktor Motivasional

Pengaruh variabel motivasional (X2) terhadap prestasi kerja petugas promosi kesehatan puskesmas Kabupaten Kotawaringin Timur diperoleh nilai koefisien positif sebesar 0,657 dengan nilai $\mathrm{t}$ statistik sebesar 2,736 dengan tingkat signifikansi 0,010 . Nilai signifikansi t tersebut menunjukkan lebih kecil dari tingkat kepercayaan 0,05, sehingga dapat disimpulkan bahwa pada tingkat kepercayaan $5 \%$ pengaruh motivasional terhadap prestasi kerja petugas promosi kesehatan Kabupaten Kotawaringin Timur adalah positif dan signifikan. Hal ini mengindikasikan bahwa jika Puskesmas di Kabupaten Kotawaringin Timur memperhatikan penilaian responden tentang faktor - 
faktor motivasional yang meliputi : perilaku dalam karir pekerjaan, komitmen pada organisasi, dan intervensi setelah pelatihan akan mempunyai pengaruh terhadap prestasi kerja pegawai.

Hasil penelitian menunjukkan bahwa petugas promosi kesehatan puskesmas di Kabupaten Kotawaringin Timur tidak mempunyai perencanaan karir yang baik dan tingkat keterlibatan yang tinggi dalam pekerjaan, sehingga mereka akan termotivasi untuk belajar. Hal ini sesuai pendapat Mathieu et al, 1992; Williams et al.,1991) yang menyatakan bahwa peserta pelatihan yang mempunyai perencanaan karir yang baik dan tingkat keterlibatan yang tinggi pada pekerjaannya akan lebih termotivasi untuk belajar.

Petugas promosi kesehatan puskesmas juga punya komitmen yang tinggi pada upaya pelatihan yang dilakukan karena penting bagi pekerjaan dan peningkatan kinerja organisasi. Menurut Tennenbaum et al (1991), menyatakan bahwa Tingkat komitmen pegawai pada organisasi berpengaruh pada pandangan mereka terhadap kegunaan dari pengalaman pelatihan awal.

Selanjutnya pegawai berpendapat bahwa perlu dilakukan evaluasi atau umpan balik pada pegawai yang telah mengikuti pelatihan. Hal ini juga akan mempengaruhi proses transfer pelatihan, khususnya motivasi untuk mentransfer pengetahuan dan skill yang baru mereka dapatkan kedalam pekerjaannya. Menurut Cheng dan Ho (2001), menyatakan peserta pelatihan yang mendapatkan evaluasi atau umpan balik yang negatif akan melakukan aktivitas pembelajaran yang rendah dari pada mereka yang mendapatkan umpan balik yang positif. Masih terdapat petugas promosi kesehatan yang tidak setuju evaluasi atau umpan balik setelah mengikuti pelatihan $(2,62 \%)$. Untuk mengatasi hal ini pihak instansi perlu menjelaskan bahwa manfaat evaluasi atau umpan balik yang akan dilakukan pada pegawai setelah mengikuti pelatihan, penting untuk melihat efektifitas pelatihan itu sendiri.
2. Faktor Lingkungan

Pengaruh variabel ketiga adalah pengaruh lingkungan (X3) terhadap prestasi kerja petugas promosi kesehatan Kabupaten Kotawaringin Timur diperoleh nilai koefisien positif sebesar 0,348 dengan nilai $\mathrm{t}$ statistik sebesar 1,745 dengan tingkat signifikansi 0,090 . Nilai signifikansi $\mathrm{t}$ tersebut menunjukkan lebih besar dari tingkat kepercayaan 0,05, sehingga dapat disimpulkan bahwa pada tingkat kepercayaan 5\% pengaruh lingkungan terhadap prestasi kerja petugas promosi kesehatan Kabupaten Kotawaringin Timur adalah positif tetapi tidak signifikan.

Hasil penelitian menunjukkan bahwa pegawai mendapatkan kesempatan untuk menerapkan ilmu atau keterampilan baru yang didapatkan dari pelatihan kedalam pekerjaannya. Ini menunjukkan kurangnya dukungan pihak instansi terhadap penerapan hasil pelatihan. Menurut Ford 1992, menyatakan bahwa peluang peluang untuk mempraktekan pengetahuan dan skill yang baru tersebut akan meyakinkan ketika peserta pelatihan diberikan kesempatan yang cukup untuk menerapkan apa yang telah dipelajari pada pekerjaannya sehingga mereka akan berusaha untuk dapat mentransfer isi / muatan pelatihan yang lebih banyak.

Hasil penelitian juga menunjukkan bahwa dalam organisasi terjadi hubungan personal yang optimal meliputi kerjasama antar pegawai dan atasan. Hal ini menunjukkan terjadinya kerjasama semua pihak dalam instansi untuk dapat menerapkan hasil pelatihan demi kemajuan organisasi. Menurut Alex Nitisemito (2000) Perusahaan hendaknya dapat mencerminkan kondisi yang mendukung kerja sama antara tingkat atasan, bawahan maupun yang memiliki status jabatan yang sama di perusahaan. Kondisi yang hendaknya diciptakan adalah suasana kekeluargaan, komunikasi yang baik, dan pengendalian diri.

Lebih lanjut ditemukan bahwa pegawai merasakan adanya proses pembelajaran yang berkesinambungan di instansi, sehingga dapat dikatakan mereka akan 
menganggap penting pelatihan yang diikutinya untuk mendukung pelaksanaan pekerjaannya. Hal ini sesuai dengan pendapat dari Cheng Ho (2001), menyatakan bahwa karyawan yang bekerja dalam lingkungan pembelajaran yang berkesinambungan akan berbagai persepsi dan harapan bahwa pembelajaran adalah penting bagi mereka dan terkait dengan pekerjaannya.

Pengaruh variabel independen (pengaruh transfer pelatihan yang terdiri dari individual, motivasional, dan lingkungan) terhadap variabel dependen (prestasi kerja) secara simultan (bersama-sama) menunjukkan nilai $F$ sebesar 128,389 dengan tingkat signifikansi lebih kecil dari 0,05 (Sig. 0,000). Karena probabilitas lebih kecil dari 0,05, maka dapat diinterpretasikan bahwa pengaruh transfer pelatihan yang terdiri dari individual, motivasional, dan lingkungan secara bersama-sama memiliki pengaruh signifikan terhadap prestasi kerja petugas promosi kesehatan Puskesmas Kabupaten Kotawaringin Timur. Menurut Steers (1984) mengemukakan umumnya orang percaya, bahwa prestasi kerja individu merupakan fungsi gabungan dari tiga faktor, yaitu : (1) Kemampuan, perangai, dan minat seorang pekerja, (2) Kejelasan dan penerimaan atas penjelasan peranan seorang pekerja, (3) Tingkat motivasi kerja. Menurut Byar dan Rue yang disadur dari buku Edi Sutrisno (2009, hal. 166) mengemukakan adanya dua faktor yang mempengaruhi prestasi kerja, yaitu faktor individu dan faktor lingkungan.

Hasil Uji Signifikansi Parsial (Uji t), hasil factor individual adalah nilai koefisien positif sebesar 1,166 dengan nilai t statistik sebesar 9,150 dengan tingkat signifikansi 0,000 yang menujukkan bahwa factor individual ini merupakan factor dominan dari factor-faktor transfer pelatihan yang mempengaruhi prestasi kerja petugas promosi kesehatan puskesmas Kabupaten Kotawaringin Timur. Hal ini berarti tidak sesuai dengan hipotesis 3 (tiga) yang menyatakan "Diduga motivasional mempunyai pengaruh dominan terhadap prestasi kerja pegawai". Keadaan ini dimungkinkan karena petugas promosi kesehatan puskesmas Kabupaten Kotawaringin Timur beranggapan bahwa dari pengaruh transfer pelatihan yang terdiri dari individual, motivasional, dan lingkungan, pada saat ini yang paling berpengaruh adalah faktor individual (pengetahuan, kepribadian, dan kemampuan). Menurut Prawirosentono (1999) kinerja seorang pegawai akan baik, jika pegawai mempunyai keahlian yang tinggi, kesediaan untuk bekerja, adanya imbalan/upah yang layak dan mempunyai harapan masa depan.

\section{Kesimpulan}

Berdasarkan hasil penelitian dan pembahasan dari Pengaruhi transfer pelatihan yang terdiri dari individual, motivasional, dan lingkungan terhadap prestasi kerja petugas promosi kesehatan puskesmas di Kabupaten Kotawaringin Timur dapat diambil kesimpulan sebagai berikut :

1. Pengaruh transfer pelatihan yang terdiri dari individual, motivasional, dan lingkungan secara nyata (parsial) mempunyai pengaruh terhadap prestasi kerja petugas promosi kesehatan puskesmas, dan dari ketiga variabel, khususnya faktor lingkungan berpengaruh positif tidak signifikan terhadap prestasi kerja petugas promosi kesehatan di Kabupaten Kotawaringin Timur.

2. Pengaruh transfer pelatihan yang terdiri dari individual, motivasional, dan lingkungan mempunyai pengaruh secara simultan terhadap prestasi kerja petugas promosi kesehatan puskesmas di Kabupaten Kotawaringin Timur

3. Pengaruh transfer pelatihan individual mempunyai pengaruh yang dominan terhadap prestasi kerja petugas promosi kesehatan puskesmas di Kabupaten Kotawaringin Timur.

\section{DAFTAR PUSTAKA}

Anderson. AH. 1994. A Proactive Model for Training Needs Analysis, Journal of European Industrial Training, Vol. 8 No. 3, pp $23-28$

Anonim. 2011. Promosi Kesehatan di Daerah Bermasalah Kesehatan. Kementerian Kesehatan RI. 
Anonim, 2016. Profil Kesehatan Kabupaten Kotawaringin Timur

Arikunto. Suharsimi. 2006. Prosedur Penelitian Suatu Pendekatan Praktik, Edisi Revisi VI,Jakarta : Rineka Cipta.

Baso. Moerad H.M. 1999. Tantangan dan Peluang Lembaga dan Profesional Pengembangan Sumber Daya Manusia Menjelang dan Dalam Era Global, Manajemen Usahawan Indonesia No. 05 Th XXVIII.

Cooper, Donald, Emory, C. William. 1996. Metode Penelitian Bisnis, Terjemahan. Jilid I. Jakarta. Erlangga

Cheng, Eddie W. L Ho Danny C.K. 2001. A Review of Transfer of Training Studies in the Past Decade, Personel Review. vol 30. No 1. pp 102-118.

Daniel, Josia, 1998. Analisis Faktor-Faktor Motivasi Terhadap Prestasi Kerja Karyawan Operasional pada PT. Scema Energy Cell Gresik, Tesis. Surabaya. Program Pasca Sarjana Universitas Airlangga.

Feldman, Daniel C, an Hugh J. Arnold. 1993. Managing Individual and Group Behavior in Organizational, Tokyo. McGraw-Hill Book Company.

Fajar, Surami. 1997. Analisis Faktor-faktor Kepuasan Kerja yang Mempengaruhi Produktivitas Karyawan Tambang Nikel Pomalao di Daerah Tingkat II Kabupaten Kolaka Sulawesi Tenggara, Tesis. Surabaya. Program Pascasarjana Universitas Airlangga.

Ghozali, Imam. 2009. Aplikasi Analisis Multivariate dengan Program SPSS. Edisi IV. Badan Penerbit Universitas Diponegoro: Semarang.

Hartati. 2005. Kesesuaian Kompensasi dan Motivasi Kerja Terhadap Prestasi Kerja Pegawai pada Sekretariat Daerah Kabupaten Magelang.

Heriansyah. 2012. Analisis Pengaruh Kepemimpinan, Insentif, Kondisi Lingkungan Kerja, Kesempatan Promosi dan Supervisi Terhadap Tingkat Kepuasan Kerja Perawat Di Ruang Rawat Inap RSUD Kotabaru.

Limbong. 2006. Pengaruh Pemberian Motivasi, Kebutuhan Pegawai dan Kepuasaan Kerja Terhadap Kinerja
Pegawai pada Kantor Pelayanan Perbendaharaan Negara Cirebon

Lubis. 2008. Pengaruh Pelatihan dan Motivasi Kerja Terhadap Kinerja Karyawan PT Perkebunan Nusantara IV (Persero) Medan.

Parlinda, Wahyuddin. 2008. Pengaruh Kepemimpinan, Motivasi, Pelatihan, dan Lingkungan Kerja Terhadap Kinerja Karyawan pada Perusahaan Daerah Air Minum Kota Surakarta.

Piet Rietveld, Lasmono. S. 1994. 87 Masalah Pokok Dalam Regresi Berganda, Edisi Pertama. Cetakan Pertama. Yogjakarta. Andi Offset.

Riduwan, 2010. Metode dan Teknik Menyusun Tesis, Cetakan VII, Penerbit Alfabeta, Bandung.

Simamora, Henry. 2001. Manajemen Sumber Daya Manusia, Edisi Kedua. Yogjakarta. STIE YKPN.

Solimun. 2011. Aplikasi Statistika Mutakhir Structural Equation Modeling (Metode Partial Least Square-PLS). Makalah Pelatihan Aplikasi Statistika-PLS Program Pascasarjana Magister Manajemen STIE Indonesia Banjarmasin Tanggal 15-16 Januari 2011: Banjarmasin.

Sugiyono, 2012. Metode Penelitian Bisnis, Bandung : Alfabeta

Sutrisno Edi, 2009. Manajemen Sumber Daya Manusia, Edisi Pertama Jakarta : Kencana Prenada Media Group

Suyanto. 2012. Pengaruh Kompensasi, Kepemimpinan dan Motivasi Kerja Terhadap Prestasi Kerja Karyawan pada PT. Permodalan Nasional Madani (Persero) Kantor Cabang Banjarmasin.

Syahruli. 2004. Analisis Faktor-faktor yang Mempengaruhi Transfer Pelatihan Terhadap Prestasi Kerja Pegawai pada Badan Kepegawaian Daerah Kabupaten Hulu Sungai Tengah.

Tim Penyusun. 2015. Pedoman Penulisan Tesis. Sekolah Tinggi Ilmu Ekonomi Pancasetia Banjarmasin.Penerbit STIE Pancasetia.

Tracy, Bruce J., Timothy R Hinkin, Scott Tannenbaum, John E Mathieu. 2001. The influence of individual 
164 Jurnal Ilmiah Ekonomi Bisnis, Vol 3, No 2, Juli 2017, hal 151 - 164

characteristic and the work Werther, Jr., William B., Devis, Keith. 1996. environtmental on varying levels of training and outcome, Human Resources Development Quaterly, Vol Personal Management and Human Resources, Internasional Edition. 12 No. 1 Spring 2001. Pp 5-23.

Singapore. McGraw-Hill. 